\title{
The Effect of R\&D Expenditure on Firm Output: Empirical Evidence from Vietnam*
}

\author{
Quan Minh Quoc BINH ${ }^{1}$, Le Thanh TUNG ${ }^{2}$
}

Received: March 20, 2020 Revised: April 11, 2020 Accepted: May 07, 2020

\begin{abstract}
The effect of research and development (R\&D) expenditure on firm output is an interesting topic, but hardly explored in developing countries due to the unavailability of data. This study investigates this topic in the context of Vietnam by utilizing a novel dataset of 343 firms listed on the Vietnam Stock Exchange in the 2010-2018 period. The effect of R\&D expenditure is examined under the production function framework. In order to obtain the robustness of the quantitative results, we estimate the production function with two coherent techniques including the OLS and 2-SLS. An instrumental variable regression technique is adopted to avoid the endogeneity problem between $R \& D$ expenditure and other variables. In our empirical analysis, we find that R\&D expenditure has a positive and significant impact on output growth. The finding is robust in both OLS and 2-SLS frameworks. Besides, the output elasticity to R\&D expenditure of our result is much higher than the estimated elasticity of other countries. The results imply that a $1 \%$ increase in R\&D expenditure in Vietnam will help to expand the output more than a $1 \%$ increase in R\&D investment in other countries. The findings from our paper provide important implications for firm managers, investors, and policymakers in Vietnam.
\end{abstract}

Keywords : R\&D Expenditure, Firm Output, Production Function, Vietnam.

JEL Classification Code: O30, O32, D22, D24

\section{Introduction}

It is widely believed that research and development (R\&D) expenditure plays a key role in enhancing firm performance (O'Mahony \& Vecchi, 2009; Sharma, 2012; Kim et al., 2018; Koutroumpis, Leiponen, \& Thomas, 2020). The success of large corporations (such as Samsung Electronics, Hyundai Motor, Huawei and Apple) has demonstrated the importance of $R \& D$ in increasing profits

*The authors kindly thank for the funding by the Vietnam Ministry of Education and Training [under the grant number KX-84/B2019MBS.04]

${ }^{1}$ First Author. Lecturer, Faculty of Economics and Public Management, Ho Chi Minh City Open University, Vietnam.

Email: binh.qmq@ou.edu.vn

${ }^{2}$ Corresponding Author. Associate Professor, Faculty of Economics and Public Management, Ho Chi Minh City Open University, Vietnam [Portal Address: No. 97, Vo Van Tan Street, Ward 6, District 3, Ho Chi Minh City, 724000, Vietnam] Email: tung.It@ou.edu.vn

(c) Copyright: The Author(s)

This is an Open Access article distributed under the terms of the Creative Commons Attribution Non-Commercial License (http://Creativecommons.org/licenses/by-nc/4.0/) which permits unrestricted noncommercial use, distribution, and reproduction in any medium, provided the original work is properly cited. and maintaining competitiveness. Griliches (1979) states that spending in R\&D will enhance a firm's stock of knowledge, leading to better innovation, which can increase output as a result of increased productivity. Nevertheless, there are also risks and costs associated with R\&D activities. Teece (1986) emphasizes that $R \& D$ activities increase the operating cost of firms, so these activities need to be accompanied with good production and marketing processes. Kim, Kim, and Cho (2014) state that R\&D brings more risk to businesses since the failure rate of this activity is very high. Therefore, important questions should be raised: Should firms from developing countries spend money on R\&D activities? Does investment in R\&D have any effect on firm output in developing markets?

In recent years, numerous empirical studies have explored the effects of R\&D expenditure on firm output in developed countries. Griliches (1991) explores the topic with US firms, while Griffith, Harrison, and Van Reenen (2006) investigate the subject with a sample of UK manufacturing listed firms. Koutroumpis, Leiponen, and Thomas (2020) examine the contribution of R\&D in a sample of large European firms. There is only a small number of studies that focus on this subject in developing countries, such as China, India or 
Bangladesh (Sharma, 2012; Xu \& Sim, 2018; Lee \& Xuan, 2019; Sharma, 2019). Nevertheless, developing countries have been contributing an indispensable role in promoting economic growth for the world economy (McGregor, 2011). Empirical research on the contribution of R\&D in the context of developing countries is crucial. This article provides contemporary evidence on the effect of R\&D expenditure on firm output in the context of Vietnam, a booming business market in the Asia-Pacific region (Tung, 2020). Although the country has achieved strong economic growth during the last 30 years (Tung, 2019; Bentzen \& Tung, 2020), investment in $\mathrm{R} \& \mathrm{D}$ is still low compared with other Southeast Asian countries. According to the World Bank (2017), Vietnam firms invest $1.6 \%$ annual revenue in R\&D activities, while the proportion is $1.9 \%$ for Cambodia firms, $2.6 \%$ for Malaysian firms, 3.6\% for Philippine firms, and $14.5 \%$ for Laos firms. We provide convincing evidence for the positive contribution of R\&D on output growth, and firms should spend more money on these activities.

There are two contributions in this paper. First, our study contributes to the literature by providing fresh evidence about the effect of $R \& D$ expenditure on firm output growth in the case of Vietnam, an emerging economy in Asia. Second, we provide important implications for firm managers, investors, and policymakers in order to increase the efficiency of businesses.

The content of our paper is structured around five sections. The next section presents the literature review. Section 3 presents the data of variables in the model, and it also outlines the methodology that will be used in regression analysis. We discuss the empirical analysis and findings in Section 4. Finally, we have conclusions and policy implications in Section 5.

\section{Literature Review}

Since the neoclassical growth theory of Solow (1956) was developed, later researchers have added $R \& D$ as an important element of economic growth. Griliches (1979) stated that productivity growth is the result of investment in R\&D activities. In the endogenous growth model, Romer (1986) pointed out that higher total output is warranted by higher $R \& D$ spending since $R \& D$ also creates positive spillover effects for society. In addition, in the study of growth theory and endogenous innovation, Grossman and Helpman (1994) emphasize that technological progress is the primary engine for economic growth for many countries in the world, and "most technological progress requires, at least at some stage, an intentional investment of profit-seeking firms or entrepreneurs". According to the authors, firms are willing to invest in $R \& D$ when there is a chance for them to enhance their profits. When firms continue to pour money into R\&D, the innovation activities will take place more quickly and lead to higher productivity as well as profits.
There are some empirical studies on the subject of R\&D and output, and these studies cover both the micro and macro level (O’Mahony \& Vecchi, 2009). In these studies, R\&D is considered as an essential input for firm knowledge that would contribute to the creation of new products, higher output growth, better technologies and higher productivity (Griliches, 1990; O’Mahony \& Vecchi, 2009; Seo, Kim, \& Lee, 2018; Koutroumpis, Leiponen, \& Thomas, 2020). At firm-level study, the first research work of Mansfield (1965) explores the effect of R\&D spending on firm productivity. Later scholars such as Audretsch and Feldmann (2004) and Cincera (2005) find a positive association between $R \& D$ and productivity as well as output; however, the impact of R\&D on output varies across the studies.

At the industry level, Griliches (1973) explores the impact of R\&D on the productivity of that industry and the spillover effects on other industries. Other scholars also investigate the impact of $R \& D$ expenditure on productivity and output growth at the regional level (Bronzini \& Piselli, 2009) as well as the country level (Griliches, 1964; Nadiri, 1980). Hall, Mairesse, and Mohnen (2010) conduct an excellent literature review of studies on $R \& D$, they find that the rates of return of R\&D are usually around $20 \%$ to $30 \%$. They conclude that there is not much difference in the calculation of the elasticities of output with respect to $\mathrm{R} \& \mathrm{D}$ when using industry data and firm data. Some studies also focus on the spillover effects of R\&D activities in one firm to other firms. Pertaining to the positive spillover effects of $R \& D$, scholars all agree that geography has an indispensable role in the spread of technology across firms and industries (Jaffe, Trajtenberg, \& Henderson, 1993; Orlando, 2004; Aiello \& Cardamone, 2008). In their seminal article, Jaffe, Trajtenberg, and Henderson (1993) use the patent citation data in the US to explore the existence of geographic knowledge spillovers. The authors conclude that geographic proximity is important for positive spillovers of R\&D. Besides, Aiello and Cardamone (2008) reach a similar conclusion in a sample of Italian firms.

Besides, Griliches (1991) finds that the elasticity of output to R\&D in US firms is 0.07 . It means that a $10 \%$ increase in R\&D spending would lead to a $0.7 \%$ increase in output. By examining a sample of UK manufacturing firms listed on the London Stock Exchange, Griffith, Harrison, and Van Reenen (2006) find that the estimated output elasticity to R\&D fluctuates in the range between 0.012 and 0.029 , depending on the model specification and regression technique. In Germany, Harhoff (1998) reports that the elasticity of output to $R \& D$ for a sample of 443 manufacturing firms is around 0.072-0.155. By employing data from four countries (US, UK, Japan, and France), O’Mahony and Vecchi (2009) find that firms operating in the R\&D intensive sector would have $2 \%$ to $5 \%$ higher productivity. In a recent study, Koutroumpis, Leiponen, and Thomas (2020) examine the contribution of 
R\&D on productivity in a sample of large European firms (in Germany, France, Sweden, and the United Kingdom) from 2004 to 2013. They find that R\&D expenditure has a larger effect on revenue for firms in Information and Communication Technologies (ICT) when compares with firms in Non-Information and Communication Technologies (non-ICT).

Relating to positive spillover effects of $R \& D$ in different countries or regions in the world, Coe, and Helpman (1995) emphasize that domestic R\&D helps to enhance productivity and output growth, but the foreign stock of knowledge is also important in explaining the growth of total factor productivity (TFP). The authors state that $R \& D$ from foreign countries would have a direct positive impact on domestic productivity through the introduction of advanced technologies and production processes and an indirect effect through the process of importing foreign goods and services. Bayoumi, Coe, and Helpman (1999) report that international trade will also help in creating the positive spillover effect of R\&D. The authors state that a country could enhance productivity and output growth simply by trading with other nations. Having the same viewpoint, Coe, Helpman, and Hoffmaister (1997) argue that developing nations can benefit from a positive spillover effect by doing international trade with developed nations rather than spending in $R \& D$ themselves.

In emerging market economies, the output elasticity to $R \& D$ also varies in different countries. Jefferson and Singh (1998) utilize the data of medium and large-sized manufacturing firms in China in 1997-1998 periods to build a knowledge production function. The authors find that the ratio of $R \& D$ spending to sale revenue has a positive impact on firm revenue. In addition, Sharma (2012) explores the impact of $R \& D$ on firm performance basing on the data of the Indian pharmaceutical industry from 1994 to 2006. The author finds the positive impact of R\&D on total factor productivity (TFP) and output. Specifically, R\&D expenditure contributes to $15 \%-19 \%$ in the increase in TFP and contributes to the output from $10 \%$ to $13 \%$. Sharma (2016) explores the impacts of in-house research and development as well as technology transfer in the productivity of Indian pharmaceutical firms from 1994 to 2010. The author employs the growth accounting and production function to examine the relationship. Surprisingly, the result indicates that R\&D intensity has a small impact on total factor productivity and output growth. However, for foreign firms, R\&D has a significant impact on firm productivity. The paper concludes that technology spillover plays an essential role in increasing the productivity of pharmaceutical firms in India.

In a recent study, Rao, Yu, and Cao (2013) investigate the long-term association between R\&D expenditure and firm value. They report that $R \& D$ expenditure has positive impacts on firm performance, but these impacts become weaker in the long-term. Xu and Sim (2018) report the positive impacts of R\&D on firm output in a sample of China and South Korean firms. Moreover, Kim et al. (2018) examine the non-linear relationship between R\&D investment and firm value by employing a sample of 563 listed companies in China during the 2005-2013 periods. They report the inverted U-shaped relationship between $\mathrm{R} \& \mathrm{D}$ and firm value. It means that firm value will increases when there is an increase in $R \& D$ expenditure, but more and more $R \& D$ expenditure is added, the firm value will eventually decrease. The inverted U-shaped relationship is also presented with low state-owned companies as well as companies with high growth opportunities. Furthermore, Sharma (2019) studies the effects of R\&D on innovation and productivity for the Bangladeshi manufacturing firms. The author finds that enterprises conducting both $R \& D$ and foreign technology transfer will have lower labor productivity.

Given the above theory and empirical evidence, we see that there are many studies about the effect of R\&D activity on output at firm, industry, region and country level in both developed and developing countries. In Vietnam, there are some micro-level studies related to the work performance of employees (Nguyen et al., 2019), or on labor productivity of employees (Tung, 2020). However, there is no empirical work that explores the effect of R\&D expenditure on firm output in the context of this economy. To the best of our knowledge, our paper is the first to consider this issue in the case of Vietnam.

\section{Methodology and Data}

\subsection{Methodology}

In order to explore the impacts of R\&D expenditure on firm output, we use the following Cobb-Douglas production function to present the relationship between inputs and output for a particular firm (see Branstetter \& Chen, 2006). In this function, $R \& D$ expenditure is considered as the main input for creating output.

$$
Y_{i}=K_{i}^{\alpha} L_{i}^{\beta} R \& D_{i}^{\psi} e^{\varepsilon i}
$$

In the next step, we follow Sharma (2012) to take the natural logarithm of both sides of the production function which gives us.

$$
\operatorname{Ln}\left(Y_{\mathrm{it}}\right)=\varphi_{0}+\varphi_{1} \operatorname{Ln}\left(\mathrm{K}_{\mathrm{it}}\right)+\varphi_{2} \operatorname{Ln}\left(\mathrm{L}_{\mathrm{it}}\right)+\varphi_{3} \operatorname{Ln}\left(\mathrm{R}_{\mathrm{it}} \mathrm{D}_{\mathrm{it}}\right)+\epsilon_{\mathrm{it}}
$$

where $\operatorname{Ln}\left(Y_{\mathrm{it}}\right)$ is the natural logarithm of firm output. $\operatorname{Ln}\left(\mathrm{K}_{\mathrm{it}}\right)$ is the natural logarithm of physical capital. $\operatorname{Ln}\left(\mathrm{L}_{\mathrm{it}}\right)$ is the natural logarithm of labour. $\operatorname{Ln}\left(R \& D_{i t}\right)$ represents the natural logarithm of R\&D expenditure. In the model, 
subscript $i$ denotes firm $i(i=1,2,3 \ldots 343)$ in period $t(2010$ 2018), and $6_{\mathrm{it}}$ is the error term.

For quantitative analysis, we estimate the model 2 with two techniques including the Ordinary Least Squares (OLS) and the Two-Stage Least Squares (2-SLS). The OLS regression focuses on the average effect of dependent variables on firm output. However, the OLS regression technique may produce biased and inconsistent coefficients in the presence of endogeneity problem (see Sharma, 2012). The problem arises when there is an existence two-way linkage between R\&D and firm output. That is, firms with higher R\&D expenditure tend to have higher output, but firms with higher output would invest more on R\&D expenditure. To overcome the problem of endogeneity, we apply the instrumental variable technique. We follow previous scholars by employing one year lagged of R\&D expenditure as an instrument for the R\&D expenditure variable (see Sharma, 2012; Reed, 2015; Bellemare, Masaki, \& Pepinsky, 2017). Finally, the Wu-Hausman test will be employed to check the existence of endogeneity in the estimated results.

\subsection{Data}

Our research data is collected from the annual audited financial statements of 343 companies listed on the Vietnam Stock Exchange during the 2010-2018 period. The firms in the dataset are the biggest firms in Vietnam conducting R\&D activities, and these firms are closely monitored by investors and audit firms. Therefore, this is the best dataset to do the research in R\&D in Vietnam until now. $Y_{i t}$ is proxied by the net revenue of the company (Unit is VND billion). $\mathrm{L}_{\mathrm{it}}$ is measured by the average number of employees in the year (Unit is labour). We employ two indicators to proxy for the physical capital $\mathrm{K}_{\mathrm{it}}$. They are the Ownership equity and the Total asset (Unit is VND billion). $R \& D_{i t}$ is measured total expenditure for R\&D activities (Unit is VND billion). Descriptive statistics for the variables are presented in Table 1 below.

The statistics in Table 1 describe a mean value of 6.285 for $\mathrm{LnY}$. The mean value of $\mathrm{LnK}$, which is measured by the total asset, is 6.401 while $\mathrm{LnK}$, which is measured by the owner's equity, is 5.542. The mean value of LnR\&D expenditure is 0.202 , indicating that Vietnamese firms have low R\&D spending in comparison with output. Finally, the mean value of $\mathrm{LnL}$ is 5.987 .

\section{Results and Discussions}

\subsection{Correlation Analysis}

The correlation analysis is a simple statistical method, however, it is popularly employed to quantitative evaluate the relationship between quantitative variables. Table 2

Table 1: Summary statistics of the dataset

\begin{tabular}{|l|c|c|c|c|c|}
\hline \multicolumn{1}{|c|}{ Variable } & Mean & Std. Dev & Min & Max & Obs \\
\hline LnY & 6.285 & 1.457 & 1.011 & 10.871 & 3087 \\
\hline LnK_Asset & 6.401 & 1.442 & 2.607 & 10.528 & 3087 \\
\hline LnK_Ownership & 5.542 & 1.351 & 2.277 & 10.176 & 3087 \\
\hline LnL & 5.987 & 1.280 & 2.079 & 10.806 & 3087 \\
\hline LnR\&D & 0.202 & 1.072 & -4.605 & 7.677 & 3087 \\
\hline
\end{tabular}

Table 2: Correlations among variables

\begin{tabular}{|c|c|c|c|c|}
\hline Variable & $\operatorname{Ln}(Y)$ & Ln(K_Ownership) & $\operatorname{Ln}(\mathrm{L})$ & Ln(R\&D) \\
\hline $\operatorname{Ln}(Y)$ & 1 & & & \\
\hline Ln(K_Ownership) & $0.7246^{*}$ & 1 & & \\
\hline $\operatorname{Ln}(\mathrm{L})$ & $0.6691^{*}$ & $0.4885^{*}$ & 1 & \\
\hline $\operatorname{Ln}(R \& D)$ & $0.1767^{*}$ & $0.1736^{*}$ & $0.1236^{*}$ & 1 \\
\hline Variable & $\operatorname{Ln}(Y)$ & Ln(K_Asset) & $\operatorname{Ln}(\mathrm{L})$ & $\operatorname{Ln}(R \& D)$ \\
\hline $\operatorname{Ln}(Y)$ & 1 & & & \\
\hline Ln(K_Asset) & $0.7974^{*}$ & 1 & & \\
\hline $\operatorname{Ln}(\mathrm{L})$ & $0.6691^{*}$ & $0.5685^{\star}$ & 1 & \\
\hline Ln(R\&D) & $0.1767^{*}$ & $0.1555^{*}$ & $0.1236^{*}$ & 1 \\
\hline
\end{tabular}

Note: * denotes statistical significant at $5 \%$ level. 
describes the correlations among all variables employed in the study. Pertaining to the Pearson correlations, the firm output is positively associated with physical capital $(0.7246$ and 0.7974$)$, labor (0.6691) and R\&D expenditure (0.1767), respectively. Taking together all the correlative analysis results, we find a positive and significant correlation between $\mathrm{R} \& \mathrm{D}$ expenditure and firm output. In order to ensure the robustness of the finding, we also present the results from regression analysis in the next section.

\subsection{Empirical Results}

The estimated result from equation 2 is presented in Table 3. R\&D expenditure variable comes to the equation with a positive sign and statistically significant at $1 \%$ level. The result implies that ceteris paribus, one percent increase in $\mathrm{R} \& \mathrm{D}$ expenditure is accompanied by 0.04 percent increase in output. Estimating the production function with OLS may produce biased and inconsistent coefficients due to the problem of endogeneity (Griliches, 1979). The problem arises when there exists a two-way linkage between R\&D and firm output. That is, firms with higher $R \& D$ tend to have higher output, but firms with higher output would invest more for R\&D activities. To overcome the problem of endogeneity, we apply the instrumental variable technique.

Besides, we employ one year lagged of R\&D as an instrument for R\&D (see Sharma, 2012; Reed, 2015; Bellemare, Masaki, \& Pepinsky, 2017). R\&D variable in the model with 2-SLS still has a positive and statistically

Table 3: Impact of R\&D expenditure on output ( $\mathrm{K}$ is presented by the Ownership equity)

\begin{tabular}{|l|c|c|}
\hline \multicolumn{3}{|c|}{ Dependent variable: Ln(Y) } \\
\hline \multicolumn{1}{|c|}{ Independent variables } & OLS & 2-SLS \\
\hline Ln(K_Ownership) & $\begin{array}{c}0.5515^{* * *} \\
(41.06)\end{array}$ & $\begin{array}{c}0.5185^{* * *} \\
(27.31)\end{array}$ \\
\hline Ln(L) & $\begin{array}{c}0.4697^{* * *} \\
(33.90)\end{array}$ & $\begin{array}{c}0.4525^{* * *} \\
(27.38)\end{array}$ \\
\hline Ln(R\&D) & $\begin{array}{c}0.0401^{* * *} \\
(2.67)\end{array}$ & $\begin{array}{c}0.3776^{* * *} \\
(2.98)\end{array}$ \\
\hline Constant & $\begin{array}{c}0.4040^{* * *} \\
(4.95)\end{array}$ & $\begin{array}{c}0.6237^{* * *} \\
(5.19)\end{array}$ \\
\hline R-square & 0.6476 & 0.5897 \\
\hline Wu-Hausman test & & $\begin{array}{c}8.3972 \\
(0.003)\end{array}$ \\
\hline Observation & 3066 & 3065 \\
\hline
\end{tabular}

Note: ***, **, *denotes significant at 1\%, 5\%, 10\%. Instrument variable is $\operatorname{LnR\& D(-1)}$ significant at $1 \%$ level. The magnitude of the R\&D coefficient in the 2-SLS model is much higher than the coefficient in the OLS model. It means that our instrument has efficiently removed the endogeneity bias. Furthermore, the result of the Wu-Hausman test shows that there is no endogeneity problem in the model. Our estimate is much higher than the estimates of Griliches (1991) for the US firms, O'Mahony and Vecchi (2009) for European firms, Branstetter and Chen (2006) for Taiwanese firms, and Sharma (2012) for Indian firms. The results imply that an increase in R\&D expenditure in Vietnam will help to expand the output more than an increase in $R \& D$ in other countries.

In addition, the physical capital, which is measured by the owner's equity and labour also show their positive contribution to output growth in both OLS and 2-SLS models. Specifically, LnK and LnL have a positive and statistically significant impact on firm output at $1 \%$ level. However, in Vietnam, capital and labor still contribute a larger share to output growth than R\&D expenditure.

We further check the robustness of the impact of R\&D expenditure on firm output by employing firm total assets as a proxy for physical capital. The result from Table 4 shows that R\&D expenditure still has positive impacts on output growth at $1 \%$ statistical significance level. The estimated coefficient of R\&D implies that other things being equal, one percent increases in $\mathrm{R} \& \mathrm{D}$ expenditure will lead to an increase on average 0.048 percent in output. R\&D activities will help firms improve existing products as well as develop new products and services. Therefore, firm revenue would be improved. We also utilize the instrumental variable to

Table 4: Impact of R\&D expenditure on output ( $\mathrm{K}$ is presented by the Total asset)

\begin{tabular}{|l|c|c|}
\hline \multicolumn{3}{|c|}{ Dependent variable: Ln(Y) } \\
\hline \multicolumn{1}{|c|}{ Independent variables } & OLS & 2-SLS \\
\hline Ln(K_Asset) & $\begin{array}{c}0.6124^{* * *} \\
(50.27)\end{array}$ & $\begin{array}{c}0.5829^{* * *} \\
(35.86)\end{array}$ \\
\hline Ln(L) & $\begin{array}{c}0.3601^{* * *} \\
(26.95)\end{array}$ & $\begin{array}{c}0.3397^{* * *} \\
(20.74)\end{array}$ \\
\hline Ln(R\&D) & $\begin{array}{c}0.0480^{* * *} \\
(3.48)\end{array}$ & $\begin{array}{c}0.4378^{* * *} \\
(3.73)\end{array}$ \\
\hline Constant & $\begin{array}{c}0.1951^{* *} \\
(2.58)\end{array}$ & $\begin{array}{c}0.4305^{* * *} \\
(3.91)\end{array}$ \\
\hline R-square & 0.7007 & 0.6229 \\
\hline Wu-Hausman test & & $\begin{array}{c}14.2026 \\
(0.0002)\end{array}$ \\
\hline Observation & 3066 & 3065 \\
\hline
\end{tabular}

Note: ***, **, *denotes significant at 1\%,5\%,10\%. Instrument variable is $\operatorname{LnR} \& D(-1)$ 
deal with the endogeneity problem. We employ one year lagged of $R \& D$ as an instrumental variable for $R \& D$. The instrumental variable technique has proved the efficiency in removing the endogeneity in the model. The result from the Wu-Hausman test shows that there is no endogeneity in the model.

The estimated coefficient of R\&D in Table 4 is not much different from that in Table 3. R\&D activities in Vietnam enable scientists to develop new product knowledge as well as technology. With advanced technology, we can produce more goods and services with the same amounts of production inputs. As a result, firm productivity also increases.

\section{Conclusions}

This paper examines the impact of $R \& D$ expenditure on firm output by employing a panel sample of 343 Vietnamese listed firms in the 2010-2018 period. Vietnam offers an interesting case for the study since it has experienced a high economic growth rate in recent years, however, investment in R\&D in the Vietnamese firms have been still quite low the previous years. In this case, the empirical question of whether R\&D investments influence the firm output in Vietnam has attracted the attention of researchers. This study introduces both panel data with the OLS and 2-SLS methods to comprehensively investigate this issue. The OLS provides an average impact of $R \& D$ on firm output, while instrumental variable with 2-SLS regression technique has efficiently removed the endogeneity problem in the model. Our findings confirm the essential role of R\&D expenditure in enhancing firm output. In addition, the estimated output elasticity to $R \& D$ expenditure in Vietnam is around $0.37 \div 0.43$, which is much higher than the estimated elasticity of other countries in the world. The results imply that a $1 \%$ increase in $R \& D$ expenditure in Vietnam will help to expand the output more than a $1 \%$ increase in $R \& D$ investment in other countries. This paper extends the R\&D expenditure-firm output literature in many ways. Firstly, the paper provides the first evidence on the relationship between R\&D and firm output in Vietnam. Secondly, we suggest meaningful implications for many stakeholders. Specifically, the results from the paper would be benefited for policy marker as well as firm managers in Vietnam.

From the policy perspective, we suggest that Vietnamese firms should invest more in $R \& D$ activities to enhance their performance in the future. In addition, the Vietnamese government should provide preferential treatment, including tax reductions and exemptions, reductions in land and water surface lease fees for new investment projects in R\&D. For example, incomes that are generated from the products of R\&D activities should get tax cuts and exemptions. New investment $R \& D$ projects should get reductions in water surface lease fees. Secondly, the government should grant concessional loans to R\&D projects. Firms will receive loans for specific R\&D projects. In the case of projects that fail, only a small proportion of the costs of the project will have to be paid back. Last, but not least, the government should promote linkages between universities and businesses in conducting R\&D activities.

Finally, this paper has some limitations. In detail, we test the effect of R\&D on Vietnam listed firm output, however, in the empirical analysis, there may be the potential of omitted variable problems in the model. We only include three independent variables that are important for firm output, including labor, physical capital, and R\&D expenditure. Besides, there are other variables that can affect output growth such as raw material, fuel consumption, and technology transfer. We are not able to control these variables due to the difficulties in collecting data.

\section{Reference}

Aiello, F., \& Cardamone, P. (2008). R\&D spillovers and firms' performance in Italy. Empirical Economics, 34(1), 143-166.

Audretsch, D. B., \& Feldman, M. P. (2004). Knowledge spillovers and the geography of innovation. Handbook of Regional and Urban Economics, 4, 2713-2739.

Bayoumi, T., Coe, D. T., \& Helpman, E. (1999). R\&D spillovers and global growth. Journal of International Economics, 47(2), 399-428.

Bellemare, M. F., Masaki, T., \& Pepinsky, T. B. (2017). Lagged explanatory variables and the estimation of causal effect. The Journal of Politics, 79(3), 949-963.

Bentzen, J., \& Tung, L. T. (2020). Regional income convergence in an emerging Asian economy: empirical evidence from Vietnam. Post-Communist Economies, (Forthcoming). https://doi.org/10 $.1080 / 14631377.2020 .1722587$

Branstetter, L., \& Chen, J. R. (2006). The impact of technology transfer and R \& D on productivity growth in Taiwanese industry: Microeconometric analysis using plant and firm-level data. Journal of the Japanese and International economies, 20(2), 177-192.

Bronzini, R., \& Piselli, P. (2009). Determinants of long-run regional productivity with geographical spillovers: the role of $\mathrm{R} \& \mathrm{D}$, human capital and public infrastructure. Regional Science and Urban Economics, 39(2), 187-199.

Cincera, M. (2005). Firms' productivity growth and R\&D spillovers: An analysis of alternative technological proximity measures. Economics of Innovation and New Technology, 14(8), 657-682.

Coe, D. T., \& Helpman, E. (1995). International R\&D spillovers. European Economic Review, 39(5), 859-887.

Coe, D. T., Helpman, E., \& Hoffmaister, A. W. (1997). North-South R\&D spillovers. The Economic Journal, 107(440), 134-149

Griliches, Z. (1964). Research expenditures, education, and the aggregate agricultural production function. American Economic Review, 54(6), 961-974. 
Griliches, Z. (1973). Research expenditures and growth accounting. Science and Technology in Economic Growth (pp. 59-95). Palgrave Macmillan, London.

Griliches, Z. (1979). Issues in assessing the contribution of research and development to productivity growth. Bell Journal of Economics, 10, 92-116.

Griliches, Z. (1990). Patents Statistics as Economic Indicators: A survey. Journal of Economic Literature, 18(4), 1661-1707.

Griliches, Z. (1991). The search for R\&D spillovers. NBER Working Paper No. 3768. National Bureau of Economic Research.

Griffith, R., Harrison, R., \& Van Reenen, J. (2006). How special is the special relationship? Using the impact of US R\&D spillovers on UK firms as a test of technology sourcing. American Economic Review, 96(5), 1859-1875.

Grossman, G. M., \& Helpman, E. (1994). Endogenous innovation in the theory of growth. Journal of Economic Perspectives, $8(1), 23-44$.

Hall, B. H., Mairesse, J., \& Mohnen, P. (2010). Measuring the Returns to R\&D. Handbook of the Economics of Innovation, 2, 1033-1082.

Harhoff, D. (1998). R\&D and productivity in German manufacturing firms. Economics of Innovation and New Technology, 6(1), 2950.

Jaffe, A. B., Trajtenberg, M., \& Henderson, R. (1993). Geographic localization of knowledge spillovers as evidenced by patent citations. The Quarterly journal of Economics, 108(3), 577598.

Jefferson, G. H., \& Singh, I. (1998). Enterprise reform in China: Ownership, transition, and performance. London: Oxford University Press.

Kim, H., Kim, Y., \& Cho, K. (2014). The effect of research and development investment and desorptive capacity on firm performance. Asian Journal of Technology Innovation, 22(2), 252-267.

Kim, W. S., Park, K., Lee, S. H., \& Kim, H. (2018). R\&D Investments and Firm Value: Evidence from China. Sustainability, 10(11), 4133.

Koutroumpis, P., Leiponen, A., \& Thomas, L. D. (2020). Small is big in ICT: the impact of R\&D on productivity. Telecommunications Policy, 44(1), 101833.

Lee, J. W., \& Xuan, Y. (2019). Effects of Technology and Innovation Management and Total Factor Productivity on the Economic Growth of China. Journal of Asian Finance, Economics and Business, 6(2), 63-73. https://doi.org/10.13106/jafeb.2019. vol6.no2.63

McGregor, H. (2011). Jim O’Neill Game Changer. Brunswick Review, 4 (Summer), 27-29.

Mansfield, E. (1965). Rates of return from industrial research and development. American Economic Review, 55(1/2), 310-322.

Nadiri, M. I. (1980). Sectoral productivity slowdown. American Economic Review, 70(2), 349-355.

Nguyen, H. M., Nguyen, C., Ngo, T. T., \& Nguyen, L. V. (2019). The Effects of Job Crafting on Work Engagement and Work
Performance: A Study of Vietnamese Commercial Banks. Journal of Asian Finance, Economics and Business, 6(2), 189201. https://doi.org/10.13106/jafeb.2019.vol6.no2.189

O’Mahony, M., \& Vecchi, M. (2009). R\&D, knowledge spillovers and company productivity performance. Research Policy, $38(1), 35-44$.

Orlando, M. J. (2004). Measuring spillovers from industrial R\&D: on the importance of geographic and technological proximity. RAND Journal of Economics, 35(4), 777-786.

Rao, J., Yu, Y., \& Cao, Y. (2013). The effect that R\&D has on company performance: comparative analysis based on listed companies of technique intensive industry in China and Japan. International Journal of Education and Research, 1(4), 1-8.

Reed, W. R. (2015). On the practice of lagging variables to avoid simultaneity. Oxford Bulletin of Economics and Statistics, 77(6), 897-905.

Romer, P. M. (1986). Increasing returns and long-run growth. Journal of Political Economy, 94(5), 1002-1037.

Seo, S. Y., Kim, S. K., \& Lee, M-L. (2018). The Effects of Knowledge Assets on the Performances of Startup Firms: Moderating Effects of Promotion Focus. Journal of Asian Finance, Economics and Business, 5(4), 187-199. https://doi. org/10.13106/jafeb.2018.vol5.no4.187

Sharma, C. (2012). R\&D and firm performance: evidence from the Indian pharmaceutical industry. Journal of the Asia Pacific Economy, 17(2), 332-342.

Sharma, C. (2016). R\&D, technology transfer and productivity in the Indian pharmaceutical industry. International Journal of Innovation Management, 20(01), 1650010.

Sharma, C. (2019). Effects of R\&D and foreign technology transfer on productivity and innovation: an enterprises-level evidence from Bangladesh. Asian Journal of Technology Innovation, 27(1), 46-70.

Solow, R. M. (1956). A contribution to the theory of economic growth. The Quarterly Journal of Economics, 70(1), 65-94.

Teece, D. J. (1986). Profting from Technological Innovation: Implications for Integration, Collaboration, Licensing and Public Policy. Research Policy, 15(6), 285-305.

Tung, L. T. (2019). Does Foreign Direct Investment Really Support Private Investment in an Emerging Economy? An Empirical Evidence in Vietnam. Montenegrin Journal of Economics, 15(1), 7-20.

Tung, L.T. (2020). Factors affecting labour productivity of employee in an Asian emerging market: Evidence in Vietnamese retail sector. International Journal of Business and Globalisation (Forthcoming).

Xu, J., \& Sim, J. W. (2018). Characteristics of corporate R\&D investment in emerging markets: Evidence from manufacturing industry in China and South Korea. Sustainability, 10(9), 3002.

World Bank (2017). Vietnam - Enhancing enterprise competitiveness and SME linkages: lessons from international and national experience. Washington, D.C. World Bank Group. 